Trinity University

Digital Commons @ Trinity

$10-2009$

\title{
Provenance of the Pythian Cave Conglomerate, Northern California: Implications for Mid-Cretaceous Paleogeography of the U.S. Cordillera
}

Kathleen D. Surpless

Trinity University, ksurples@trinity.edu

Gregory Alan Augsburger

Trinity University

Follow this and additional works at: https://digitalcommons.trinity.edu/geo_faculty

Part of the Earth Sciences Commons

\section{Repository Citation}

Surpless, K. D., \& Augsburger, G. A. (2009). Provenance of the Pythian cave conglomerate, northern California: Implications for mid-Cretaceous paleogeography of the U. S. Cordillera. Cretaceous Research, 30(5), 1181-1192. doi: 10.1016/j.cretres.2009.05.005

This Article is brought to you for free and open access by the Geosciences Department at Digital Commons @ Trinity. It has been accepted for inclusion in Geosciences Faculty Research by an authorized administrator of Digital Commons@ Trinity. For more information, please contact jcostanz@trinity.edu. 


\title{
Provenance of the Pythian Cave conglomerate, northern California: implications for mid-Cretaceous paleogeography of the U.S. Cordillera
}

\author{
Kathleen D. Surpless*, Gregory A. Augsburger ${ }^{1}$ \\ Department of Geosciences, Trinity University, One Trinity Place, San Antonio, TX 78212, USA
}

\section{A R T I C L E I N F O}

\section{Article history:}

Received 30 January 2009

Accepted in revised form 25 May 2009

Available online 6 June 2009

\section{Keywords:}

Provenance

Detrital zircon

Klamath Mountains

Pythian Caves

Albian

Cenomanian

\begin{abstract}
A B S T R A C T
Provenance analysis of middle Cretaceous sedimentary rocks can help distinguish between disparate tectonic models of Cretaceous Cordilleran paleogeography by establishing links between sediment and source, as well as between currently separated basins. This study combines new detrital zircon age data and compositional data with existing provenance data for the Pythian Cave conglomerate, an informallynamed unit deposited unconformably on the eastern Klamath Mountains, to test possible correlations between the Pythian Cave conglomerate and similar-age deposits in the Hornbrook Formation and the Great Valley Group. These provenance results indicate that restoring Late Cretaceous clockwise rotation of the Blue Mountains adds a significant sediment source for Cretaceous basins previously associated with only the Klamath Mountains (e.g., the Pythian Cave conglomerate and Hornbrook Formation) or a combined Klamath-Sierran source (e.g., Great Valley Group). Comparison of the Pythian Cave conglomerate with the Klamath River Conglomerate and the Lodoga petrofacies suggests that the Pythian Cave conglomerate system was separate from the nearby Hornbrook Formation and was probably related to the Lodoga petrofacies of the Great Valley Group.
\end{abstract}

(c) 2009 Elsevier Ltd. All rights reserved.

\section{Introduction}

Despite a vast amount of study, the Cretaceous paleogeography of the North American Cordillera remains uncertain (e.g., Monger, 1977; Miller, 1987; Cowan et al., 1997; Ward et al., 1997; DeGraaffSurpless et al., 2003; Dickinson, 2004; Housen and Dorsey, 2005; Haggart et al., 2006; Wyld et al., 2006). Disruption and reorganization of the North American continental margin, extensive Tertiary volcanic cover, and significant erosion since Cretaceous time complicate interpretations of Cretaceous paleogeography. Thus, sedimentary rocks associated with the eroded remnants of Mesozoic magmatic arcs may provide the most complete record of Mesozoic geology available. Many of the basin deposits exposed today in the Cordillera are potentially disconnected from their sediment sources, and their original configuration relative to each other and to the North American craton remains uncertain (e.g., Cowan et al., 1997; Ward et al., 1997; Housen and Dorsey, 2005; Wyld et al., 2006).

\footnotetext{
* Corresponding author.

E-mail address: ksurples@trinity.edu (K.D. Surpless).

1 Present address: School of Geology and Geophysics, The University of Oklahoma, 100 East Boyd Street, Suite 810, Norman, OK 73019, USA.
}

Reconstructions of the Cretaceous Cordillera in the western United States vary significantly. For example, Miller et al. (1992) and Nilsen (1984) allow for very little post-Cretaceous terrane translation and connect the Sierra Nevada Mountains, Klamath Mountains, and Blue Mountains into a single magmatic arc during Cretaceous time, with a single, massive forearc basin that included the Great Valley Group, the Hornbrook Formation, and the Ochoco basin. In contrast, Wyld et al.'s (2006) tectonic model for the midCretaceous (ca. $100 \mathrm{Ma}$ ) restores known and hypothesized fault motion in the Cordillera, resulting in a combined Hornbrook-Ochoco Basin that was separate from the Great Valley Group to the south.

Provenance analysis of sedimentary rocks deposited during the middle Cretaceous can help distinguish between these models by establishing possible links between sediment and source, as well as highlighting potential connections between currently separated basins. The provenance of the informally-named Pythian Cave conglomerate, a middle Albian deposit (Jameossanaie and LindsleyGriffin, 1993; Lindsley-Griffin et al., 1993) that lies unconformably on the Yreka subterrane of the Eastern Klamath terrane (Fig. 1), places important constraints on the mid-Cretaceous paleogeography of the Klamath Mountains, Hornbrook Formation, Sierra Nevada Mountains, and Great Valley Group.

This study combines new detrital zircon age data and compositional data with existing provenance data for the Pythian Cave 


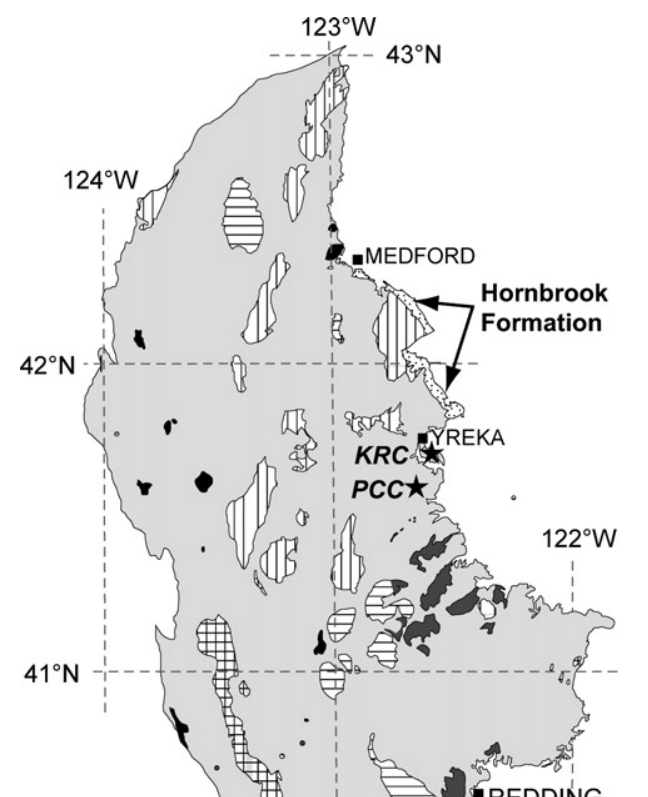

Hornbrook Formation, Pythian Cave conglomerate, and Great Valley Group

$\star \quad$ Sample locality

Northern Sierran terranes and Western

Metamorphic Belt; Klamath terranes

\section{PLUTONIC ROCKS}

Sierra Nevada Cretaceous batholith

(mainly 125-82 Ma)

$\sim 140$ Ma plutons

$\sim 150$ Ma plutons

|III $\sim 160$ Ma plutons

册 170 Ma plutons

> 190 Ma plutons

$\ominus \quad$ Dated intrusive (pattern-coded) of small $121^{\circ} \mathrm{W}$ or unknown extent

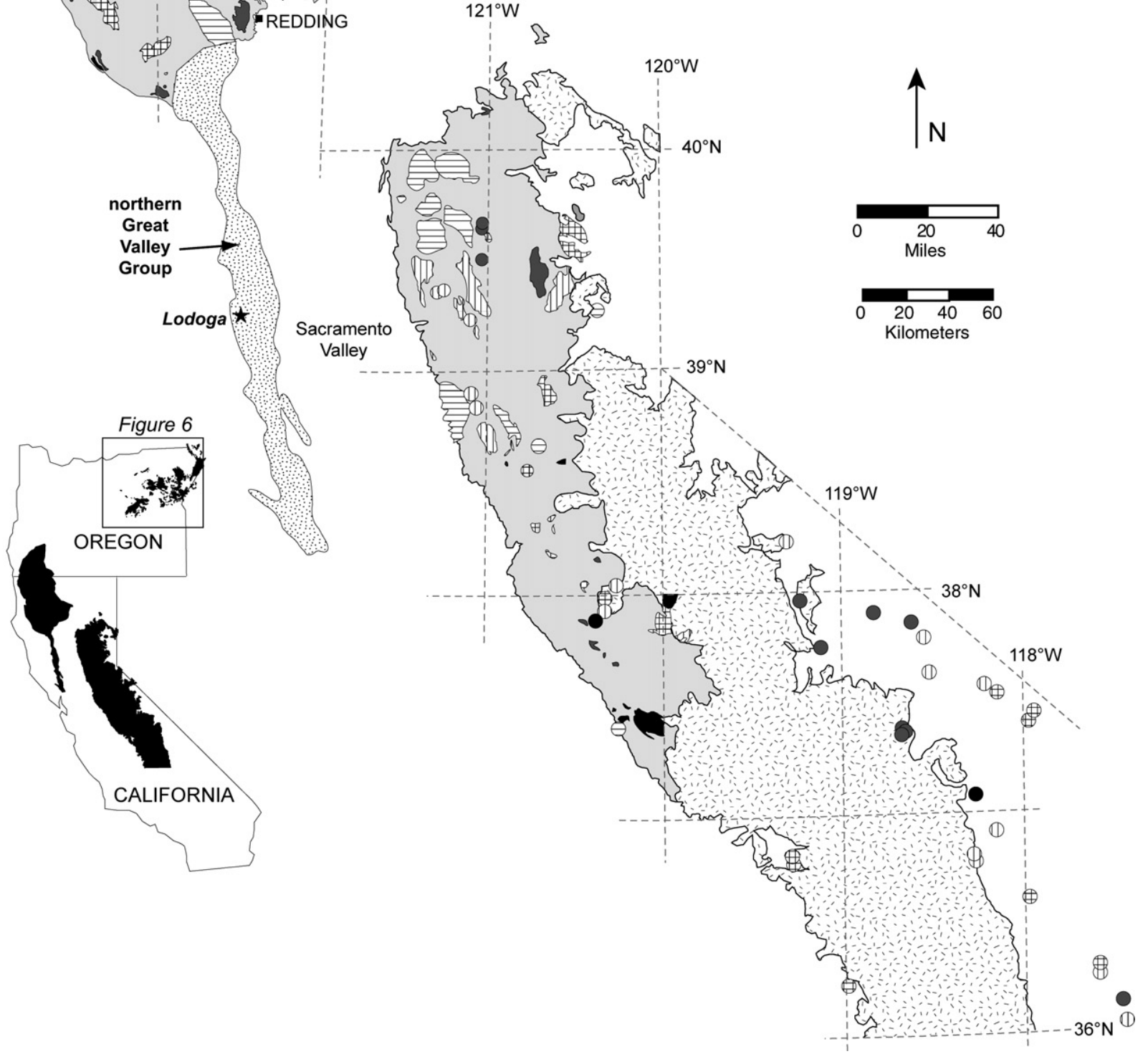

Fig. 1. Simplified geologic map of the Klamath Mountains, Sierra Nevada terranes, and Cretaceous sedimentary outcrop. Sample sites indicated by stars. Inset map shows location of Fig. 6, Blue Mountains province. Map modified from Irwin (2003). 
conglomerate to test possible correlations between the Pythian Cave conglomerate and similar-age deposits in the Hornbrook Formation and the Great Valley Group. The resulting detailed provenance analysis indicates that the Pythian Cave conglomerate matches the Lodoga petrofacies of the Great Valley Group to the south more closely than the more proximal Klamath River Conglomerate member of the Hornbrook Formation. The provenance of the Pythian Cave conglomerate suggests the presence of a Jurassic-Cretaceous volcanic arc source east or northeast of the Klamath Mountains, with sediment transported from the arc to the west and south. This southerly-directed Albian drainage system linked the Great Valley Group and Klamath Mountains by middle Albian time, and was separate from the east- and northeastdirected system that formed the Klamath River Conglomerate member of the Hornbrook Formation during Cenomanian time.

\section{Description of mid-Cretaceous sedimentary deposits}

\subsection{The Pythian Cave conglomerate}

The main outcrop of the Pythian Cave conglomerate occurs about $15 \mathrm{~km}$ south-southeast of Yreka, California (Table 1), and measures up to 60 meters in thickness over an aerial extent of about $0.25 \mathrm{~km}$. Four nearby occurrences of poorly-consolidated volcanicrich conglomerate have been correlated with the Pythian Cave conglomerate, but may be reworked Tertiary terrace gravels (Lindsley-Griffin et al., 1993), and are not included in this study. The Pythian Cave conglomerate rests on Late Proterozoic and Early Devonian age rocks of the Yreka subterrane of the Eastern Klamath terrane (Lindsley-Griffin et al., 2008). However, the abundance of basaltic and andesitic volcanic clasts in the Pythian Cave conglomerate appears to be exotic to the Klamath Mountains and differs from the primarily metamorphic clasts in the basal Hornbrook Formation that are largely derived from the Klamath Mountains (Barats et al., 1984).

The Pythian Cave conglomerate was originally considered Cretaceous and informally correlated with the Hornbrook Formation (Mack, 1960), but Hotz (1977) considered the conglomerate of Tertiary age based on the similarity between its distinctive volcanic clasts and Tertiary volcanic rocks of the Western Cascades. A more recent pollen taxonomy study dated the Pythian Cave conglomerate as middle Albian age (Jameossanaie and Lindsley-Griffin, 1993), slightly older than the Hornbrook Formation.

The Pythian Cave conglomerate contains abundant sandstone lenses, which increase in frequency in the upper 20 meters of the outcrop. Thick conglomerate units (up to $10 \mathrm{~m}$ thick) characterize the lower portion of the outcrop, with pronounced imbrication of elongate cobbles that average $8-12 \mathrm{~cm}$ along the long axis, but range from 1 to more than $30 \mathrm{~cm}$ long (Augsburger et al., 2008). Cobble imbrication permits determination of a consistent $\mathrm{S}$ to SW paleoflow direction (Wetzstein, 1986; Lindsley-Griffin et al., 1993). The sandstone lenses consist of medium to coarse sand grain size and display both large-scale and small-scale cross-bedding, with cross-bed thicknesses ranging from several centimeters to a meter.

Table 1

Sample locations

\begin{tabular}{lll}
\hline Sample & Latitude & Longitude \\
\hline KRC (Oberlin Road) & $\mathrm{N} 41^{\circ} 42.755^{\prime}$ & $\mathrm{W} 122^{\circ} 37.072^{\prime}$ \\
KRC (Interstate 5) & $\mathrm{N}^{\circ} 04.764^{\prime}$ & $\mathrm{W} 122^{\circ} 36.025$ \\
PCC & $\mathrm{N}^{\circ} 35.472^{\prime}$ & $\mathrm{W} 122^{\circ} 35.163^{\prime}$ \\
Lodoga (KDS104) & $\mathrm{N} 39^{\circ} 21.196^{\prime}$ & $\mathrm{W} 122^{\circ} 24.213^{\prime}$ \\
Lodoga (KDS105) & $\mathrm{N} 39^{\circ} 21.574^{\prime}$ & $\mathrm{W} 122^{\circ} 26.330^{\prime}$ \\
Lodoga (KDS106) & $\mathrm{N} 39^{\circ} 21.308^{\prime}$ & $\mathrm{W} 122^{\circ} 27.633^{\prime}$ \\
\hline
\end{tabular}

Because of the abundant large, well-rounded volcanic cobbles and sand lenses with immature, clay-rich sediment, the Pythian Cave conglomerate was originally interpreted as a river conglomerate deposited in a high energy environment close to its sediment source (Hotz, 1977). Additional evidence suggesting deposition in a proximal, high-gradient braided fluvial system within an alluvial fan complex includes crude horizontal stratification, flat-based, extensive, sheet-like sediment channels with low depth-to-width ratios, a low variance in paleocurrent direction, and the absence of epsilon cross-stratification typical of meandering fluvial deposits (Wetzstein, 1986; Lindsley-Griffin et al., 1993). A pollen taxonomy study confirmed the near-source river system setting, based on the relative abundance of gymnosperm and angiosperm pollen (Jameossanaie and Lindsley-Griffin, 1993).

\subsection{The Lodoga petrofacies of the Great Valley Group}

The Great Valley Group forearc basin strata crop out in a homocline along the western margin of California's Central Valley (Fig. 1), and unconformably rest on eastern Klamath terranes to the north, Sierran arc and associated foothill terranes to the east, and are in fault contact with the Franciscan accretionary complex to the west (Ingersoll, 1979; Irwin, 1981). Cretaceous paleocurrent indicators and sequence stratigraphic studies provide evidence for both axial (north-to-south) and transverse (east-to-west) sediment transport in the basin (Ingersoll, 1979; Moxon, 1988, 1990; Williams, 1997). In the northern Great Valley Group, sediment dispersal directions changed from primarily south-directed in the Late Jurassic to south- and west-directed in the Cretaceous (Ojakangas, 1968; Ingersoll, 1979). Petrographic studies divide the northern Great Valley Group into six major petrofacies based on the relative abundance of quartz, feldspar, and lithic grains in sandstone (Fig. 2; Ojakangas, 1968; Dickinson and Rich, 1972; Ingersoll, 1979, 1981, 1983; Graham and Ingersoll, 1981), which reflect variations in volcanism versus erosion in the adjacent arc.

\begin{tabular}{|c|c|c|}
\hline Age & $\begin{array}{c}\text { Great Valley Group } \\
\text { Petrofacies }\end{array}$ & $\begin{array}{c}\text { Hornbrook Formation } \\
\text { members }\end{array}$ \\
\hline MAASTRICHTIAN & \multirow{2}{*}{ Rumsey } & \multirow{12}{*}{$\underbrace{\text { TERTIARY }}_{\text {Rocky Gul }}$} \\
\hline CAMPANIAN & & \\
\hline SANTONIAN & & \\
\hline CONIACIAN & \multirow[t]{2}{*}{ Cortina } & \\
\hline TURONIAN & & \\
\hline CENOMANIAN & Boxer & \\
\hline ALBIAN & \multirow{2}{*}{ Lodoga } & \\
\hline APTIAN & & \\
\hline BARREMIAN & \multirow{4}{*}{ Stony Creek } & \\
\hline HAUTERIVIAN & & \\
\hline VALANGINIAN & & \\
\hline BERRIASIAN & & \\
\hline
\end{tabular}

Fig. 2. Schematic stratigraphy for the northern Great Valley Group (redrawn from Ingersoll, 1979) and the Hornbrook Formation (from Nilsen, 1993). Members of the Hornbrook Formation are time-transgressive (Nilsen, 1993). 
Biostratigraphy of the Lodoga petrofacies of the Great Valley Group indicates an Aptian-Albian age based on bivalves, ammonites, and microfossils in samples collected throughout the Lodoga outcrops along the western Sacramento Valley (Jones et al., 1969; Imlay and Jones, 1970; Bralower et al., 1990). The Lodoga petrofacies is characterized by high total quartz and feldspar and variable lithic grain content, and was likely derived from a combination of plutonic, metamorphic, and reworked sedimentary sources (Ingersoll, 1983).

\subsection{The Klamath River Conglomerate member of the Hornbrook Formation}

The Hornbrook Formation is a Cretaceous overlap assemblage that rests unconformably on Paleozoic, Triassic, and Jurassic terranes of the Klamath Mountains (Fig. 1; Nilsen, 1993). The Hornbrook Formation was deposited in a nonmarine alluvial and fluvial system during Albian-Cenomanian time, and evolved into a shallow marine, outer shelf, and finally deep marine environment by Maastrichtian time (Nilsen, 1993). The Hornbrook Formation is well-exposed on the eastern flank of the Klamath Mountains, and its stratigraphy, sedimentology, and tectonic framework was established by Nilsen $(1984,1993)$.

The Klamath River Conglomerate forms the basal member of the Hornbrook Formation (Fig. 2), and was deposited in alluvial fans and braided and meandering fluvial environments (Nilsen, 1993). The dominance of spores and rare occurrence of marine acritarchs in the Klamath River Conglomerate pollen assemblages confirm a lower fluvial regime dominated by ferns and occasionally inundated by shallow marine water (Jameossanaie and Lindsley-Griffin, 1993). The depositional age of the Klamath River Conglomerate is bracketed by the ages of Jurassic-Cretaceous plutons in the Klamath basement, and the Albian to early Coniacian age of the timetransgressive Osburger Gulch member that lies conformably above the Klamath River Conglomerate (Nilsen, 1993). Because it conformably underlies the marine strata of the Osburger Gulch member, the Klamath River Conglomerate could be Albian, Cenomanian, and Turonian in age. Palynological data from the Klamath River Conglomerate near Yreka indicate a middle Cenomanian age (Jameossanaie and Lindsley-Griffin, 1993), but the lack of fossils in other areas of the Klamath River Conglomerate prevents any determination of significant areal variations in age (Nilsen, 1993). The Klamath River Conglomerate is laterally discontinuous and rests unconformably on metamorphic rocks and Jurassic plutons of the Klamath Mountains (Barats et al., 1984). Conglomerate clast imbrication and sandstone cross-stratification at southern Klamath River Conglomerate localities indicate north to northwest sediment transport (Barats et al., 1984; Nilsen, 1993).

\section{Comparison of Cretaceous basins}

\subsection{Conglomerate clast composition and sandstone petrography}

Conglomerate clast counts conducted in the upper and lower sections of the Pythian Cave conglomerate yield similar results, with the majority of clasts (53\%) identified as porphyritic volcanic cobbles (Fig. 3 and Table 2), consistent with previous clast counts conducted on the Pythian Cave conglomerate (Wetzstein, 1986; Lindsley-Griffin et al., 1993). Cobble petrography revealed intense hydrothermal alteration of volcanic rocks, with some cobbles displaying complete alteration and replacement within the clast. Point-counts of three sandstone samples (following the method of Dickinson, 1970) designate similar provenance of a dissected volcanic arc when plotted on a QFL diagram (Fig. 4; provenance fields from Dickinson et al., 1983; Table 3). These results suggest
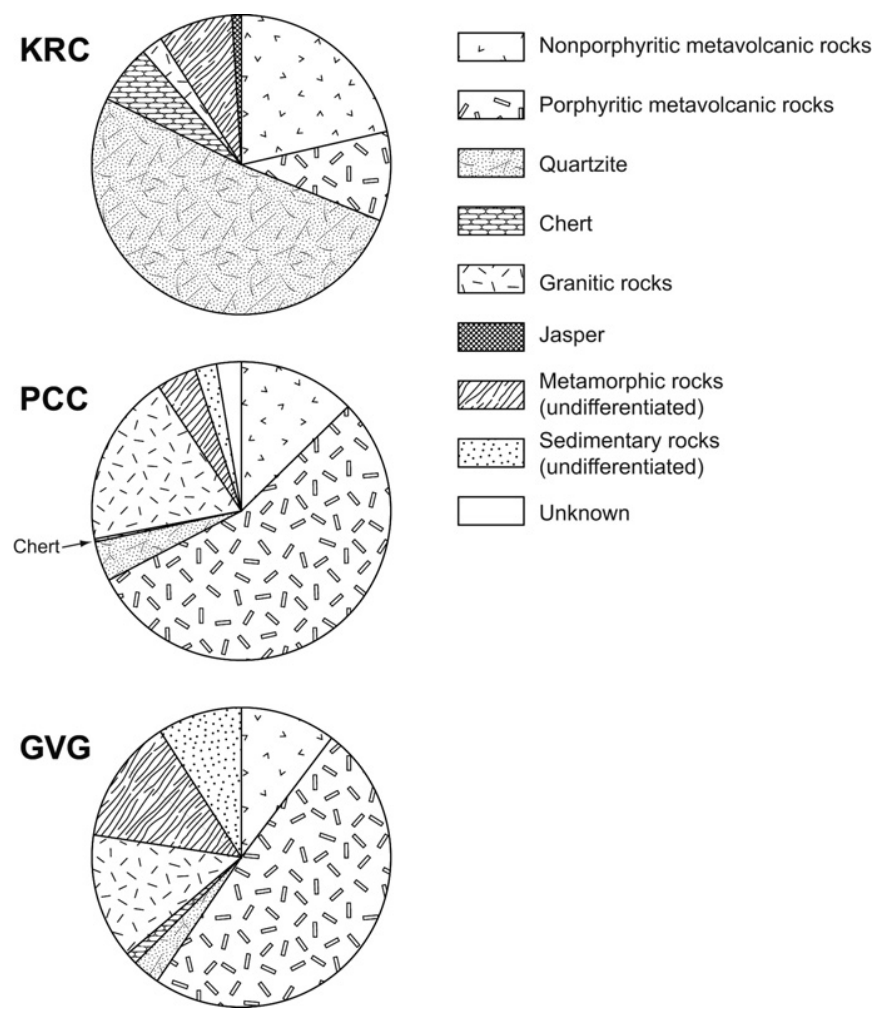

Fig. 3. Conglomerate clast compositions for the Klamath River Conglomerate (KRC at Oberlin Road outcrop; data from Beverly et al., 2008), Pythian Cave conglomerate (PCC), and the Bidwell Point conglomerate of the Great Valley Group (GVG; data from Bertucci, 1983).

a volcanic arc as the sediment source for both Pythian Cave conglomerate sandstone and conglomerate, consistent with previous interpretations (Wetzstein, 1986; Lindsley-Griffin et al., 1993).

The Lodoga petrofacies of the Great Valley Group does not contain significant conglomerate lenses, so comparison of conglomerate clast composition is based on the Valanginian-age Bidwell Point conglomerate within the upper Stony Creek petrofacies. Clast compositions from the Bidwell Point lens are dominantly porphyritic metavolcanic rocks (50\%), granite (18\%), nonporphyritic metavolcanic rocks (8\%), and smaller amounts of metasedimentary rocks, sedimentary rocks, and metamorphic rocks (Fig. 3 and Table 2; Bertucci, 1983). Extensive sandstone petrography of the Lodoga petrofacies reveals high quartz, low feldspar (mostly plagioclase), variable lithic content, and low metamorphic content (Ingersoll, 1983). The Lodoga sandstone petrofacies plots in the recycled orogen, transitional arc, and dissected arc provenance fields of a ternary QFL diagram (Fig. 4; fields from Dickinson et al., 1983; Table 3), and was likely derived from reworked sedimentary sequences as well as plutonic and metamorphic sources (Ingersoll, 1983).

Conglomerate clast counts in the Klamath River Conglomerate vary by location, with southern localities containing abundant quartzite and fewer nonporphyritic metavolcanic clasts, and northern locations containing fewer quartzite and more nonporphyritic metavolcanic clasts (Barats et al., 1984). The southern Klamath River Conglomerate exposures near Yreka (closest to the Pythian Cave conglomerate outcrop) include abundant quartzite (50\%), nonporphyritic metavolcanic rocks $(20 \%)$, porphyritic metavolcanic rocks (10\%), and smaller percentages of metasedimentary rocks, chert, granite, and jasper (Fig. 3 and Table 2; Beverly et al., 
Table 2

Conglomerate clast count data

\begin{tabular}{|c|c|c|c|c|}
\hline & PCC & $\begin{array}{l}\text { KRC (Beverly } \\
\text { et al., 2008) }\end{array}$ & $\begin{array}{l}\text { KRC (Barats } \\
\text { et al., 1984) }\end{array}$ & $\begin{array}{l}\text { Bidwell Point mean \% } \\
\text { (7 samples) (Bertucci, 1983) }\end{array}$ \\
\hline Nonporphyritic metavolcanic rocks & 34 & 10 & 23 & 10.3 \\
\hline Porphyritic metavolcanic rocks & 162 & 0 & 0 & 49.2 \\
\hline Quartzite & 13 & 57 & 45 & 3 \\
\hline Chert & 0 & 0 & 12 & 1.3 \\
\hline Granitic rocks & 53 & 0 & 0 & 13.6 \\
\hline Jasper & 0 & 0 & 0 & 0 \\
\hline Metamorphic rocks (undifferentiated) & 6 & 6 & 3 & 13.5 \\
\hline Sedimentary rocks (undifferentiated) & 8 & 18 & 0 & 9.1 \\
\hline Unknown & 24 & 9 & 0 & 0 \\
\hline Total & 300 & 100 & 83 & $100 \%$ \\
\hline
\end{tabular}

2008; Barats et al., 1984). At the southern locality, the clast-supported conglomerate occurs in several fining-upward lenses that are interbedded with fine- to medium-grain sandstone (Barats et al., 1984). Sandstone petrography of the Klamath River Conglomerate member reveals abundant monocrystalline quartz, moderate feldspar (mostly plagioclase), and low lithic content, with provenance overlapping the transitional continental, basement uplift, and recycled orogen fields of a ternary QFL diagram (Fig. 4; fields from Dickinson et al., 1983; data from Golia and Nilsen, 1984; Beverly et al., 2008; Table 3).

\subsection{Detrital zircon age signatures}

Because zircon generally does not become abundant until a melt is intermediate to felsic in composition (Poldervaart, 1956; Watson, 1979), the most prevalent sources of the detrital zircon grains found in Cretaceous Cordilleran basins are the felsic plutonic arc rocks and supracrustal metamorphic components of the country rock and adjacent terranes. Detrital zircon rarely occurs in samples lacking detrital quartz (Gehrels et al., 2006), and zircon in volcanic rocks tends to be smaller than in plutonic equivalents (Poldervaart, 1956). Thus, the Mesozoic detrital zircon age distributions from Pythian

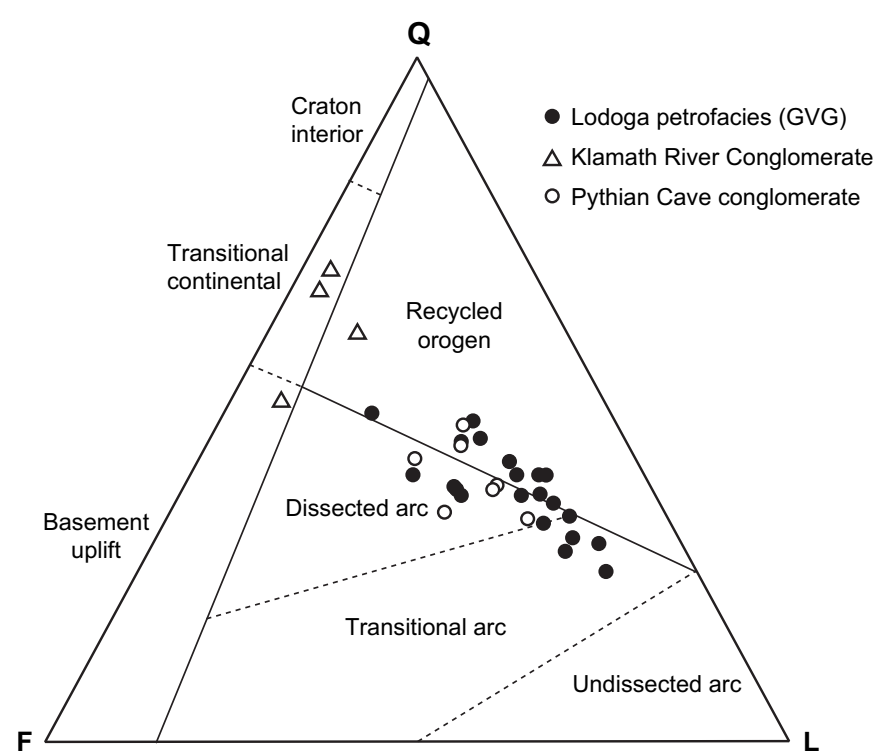

Fig. 4. QFL plot of data from the Lodoga petrofacies of the Great Valley Group (Albianage samples only; data from Ingersoll, 1983), the Klamath River Conglomerate member of the Hornbrook Formation (data from Golia and Nilsen, 1984; Beverly et al., 2008), and the Pythian Cave conglomerate (data from this study and Lindsley-Griffin et al., 1993). Provenance fields from Dickinson et al. (1983).
Cave conglomerate, Klamath River Conglomerate, and Lodoga sandstone samples (Fig. 5) largely reflect plutonic ages in source regions, with lesser input from supracrustal metamorphic and intermediate volcanic cover rocks. The detrital zircon age data are presented in probability density curves, which represent the summed Gaussian distributions of each age and associated uncertainty at one sigma. The maximum depositional age of a sample is based on the age of the youngest age peak (containing three or more grains) in an age distribution.

Detrital zircon age data from three Pythian Cave conglomerate sandstone samples yield remarkably similar age distributions, indicating that the sources remained consistent throughout deposition, and are thus presented here in one combined probability density curve (Fig. 5). The majority of ages form a broad Early Cretaceous age peak $(\sim 130-150 \mathrm{Ma})$, with smaller peaks at $166 \mathrm{Ma}, 177 \mathrm{Ma}, 185 \mathrm{Ma}$, and $199 \mathrm{Ma}$ (Fig. 5). None of the ages in the Pythian Cave conglomerate are pre-Mesozoic. The youngest robust peak age is $131.8 \pm 2.5 \mathrm{Ma}$ (26 grains) and provides the maximum depositional age. Four granite cobbles collected from the base and top of the Pythian Cave conglomerate outcrop provide additional age information about what must have been a proximal source. All four cobbles yield the same age (within error) of 187-188 Ma $(187.4 \pm 4.2 \mathrm{Ma} ; \quad 187.4 \pm 3.6 \mathrm{Ma} ; \quad 187.5 \pm 3.6 \mathrm{Ma} ; \quad$ and $188.3 \pm 4.5 \mathrm{Ma}$; Fig. 5).

Detrital zircon analysis of three samples from the Lodoga petrofacies of the Great Valley Group reveals a broad Early Cretaceous age peak ( 135-155 Ma), with smaller Middle and Late Jurassic peaks ( $\sim 164 \mathrm{Ma}$ and $\sim 159 \mathrm{Ma}$ ), and a few Early Jurassic and Early Triassic ages (Fig. 5). Only 7\% (13 out of 177 ages) of the ages in the Lodoga petrofacies are pre-Mesozoic. The youngest robust peak age in the Lodoga is $130.9 \pm 2.4 \mathrm{Ma}$ (9 grains), although there is a small age peak at $125 \pm 3.4 \mathrm{Ma}$ (3 grains).

The detrital zircon age distribution from one sandstone sample from the Klamath River Conglomerate contains a broad MiddleLate Jurassic age peak ( $\sim 168-155 \mathrm{Ma}$ ), a secondary latest Jurassic peak ( $148 \mathrm{Ma}$ ), and much smaller peaks at $\sim 135 \mathrm{Ma}, 171 \mathrm{Ma}$, and $187 \mathrm{Ma}$, with no pre-Mesozoic ages (Fig. 5). The youngest peak age in the Klamath River Conglomerate is $136.7 \pm 2.2$ Ma (9 grains).

The degree of overlap calculated between two detrital zircon age distributions compares the number of ages (with associated uncertainties) that occur in both distributions without considering the relative abundance of these ages in either distribution. An overlap value of one indicates samples have all ages in common, while an overlap value of zero indicates no common ages between samples. Confirming the visual inspection of the density probability curves, the overlap between all three of these units is high, with the greatest overlap occurring between the Pythian Cave conglomerate and Klamath River Conglomerate (0.863), followed closely by overlap between the Pythian Cave conglomerate and Lodoga 
Table 3

Sandstone point count data

\begin{tabular}{|c|c|c|c|c|c|c|c|c|c|c|c|c|c|c|}
\hline & Qm & Qp & Chert & $\mathrm{P}$ & $\mathrm{K}$ & Lv & $\mathrm{Lm}$ & Ls & $\mathrm{Hv}$ & Mica & Total & Q & $\mathrm{F}$ & $\mathrm{L}$ \\
\hline KRC 07-HB-02 (Oberlin Road; Beverly et al., 2008) & 139 & 19 & 0 & 26 & 48 & 17 & 11 & 4 & 25 & 46 & 371 & 0.60 & 0.28 & 0.12 \\
\hline KRC 82TN 17A (Oberlin Road; Golia and Nilsen, 1984) & 62 & 7 & 0 & 27 & 0 & 4 & 0 & & & & 100 & 0.69 & 0.27 & 0.04 \\
\hline KRC 82TN 17B (Oberlin Road; Golia and Nilsen, 1984) & 60 & 6 & 0 & 30 & 0 & 4 & 0 & & & & 100 & 0.66 & 0.30 & 0.04 \\
\hline KRC 07-HB-09 (Interstate 5; Beverly et al., 2008) & 109 & 12 & 0 & 43 & 62 & 13 & 2 & 2 & 60 & 30 & 398 & 0.50 & 0.43 & 0.07 \\
\hline \multicolumn{15}{|l|}{ All Lodoga data from Ingersoll, 1983} \\
\hline Lodoga $75-107$ & 36 & 1 & 0 & 26 & 0 & 36 & 0 & 0 & 0 & 0 & 99 & 0.37 & 0.26 & 0.36 \\
\hline Lodoga $75-110$ & 32 & 5 & 0 & 26 & 0 & 37 & 0 & 0 & 0 & 0 & 100 & 0.37 & 0.26 & 0.37 \\
\hline Lodoga $75-111$ & 41 & 6 & 0 & 19 & 0 & 34 & 0 & 0 & 0 & & 100 & 0.47 & 0.19 & 0.34 \\
\hline Lodoga $77-7$ & 22 & 6 & 0 & 16 & 0 & 56 & 0 & 0 & 0 & & 100 & 0.28 & 0.16 & 0.56 \\
\hline Lodoga 77-17 & 27 & 9 & 0 & 26 & 0 & 38 & 0 & 0 & 0 & & 100 & 0.36 & 0.26 & 0.38 \\
\hline Lodoga 77-23 & 30 & 9 & 0 & 17 & 0 & 44 & 0 & 0 & 0 & & 100 & 0.39 & 0.17 & 0.44 \\
\hline Lodoga 77-24 & 46 & 2 & 0 & 32 & 0 & 20 & 0 & 0 & 0 & & 100 & 0.48 & 0.32 & 0.20 \\
\hline Lodoga $77-26$ & 25 & 14 & 0 & 13 & 0 & 48 & 0 & 0 & 0 & & 100 & 0.39 & 0.13 & 0.48 \\
\hline Lodoga 77-27 & 28 & 7 & 0 & 14 & 0 & 51 & 0 & 0 & & & 100 & 0.35 & 0.14 & 0.51 \\
\hline Lodoga 77-30 & 17 & 8 & 0 & 12 & 0 & 63 & 0 & 0 & & & 100 & 0.25 & 0.12 & 0.63 \\
\hline Lodoga 77-31 & 22 & 7 & 0 & 11 & 0 & 60 & 0 & 0 & & & 100 & 0.29 & 0.11 & 0.60 \\
\hline Lodoga 77-32 & 19 & 11 & 0 & 14 & 0 & 56 & 0 & 0 & & & 100 & 0.30 & 0.14 & 0.56 \\
\hline Lodoga 77-34 & 24 & 9 & 0 & 13 & 0 & 54 & 0 & 0 & & & 100 & 0.33 & 0.13 & 0.54 \\
\hline Lodoga 77-40 & 38 & 1 & 0 & 31 & 0 & 30 & 0 & 0 & & & 100 & 0.39 & 0.31 & 0.30 \\
\hline Lodoga 77-48 & 25 & 11 & 0 & 18 & 0 & 46 & 0 & 0 & & & 100 & 0.36 & 0.18 & 0.46 \\
\hline Lodoga 77-55 & 33 & 8 & 0 & 17 & 0 & 42 & 0 & 0 & & & 100 & 0.41 & 0.17 & 0.42 \\
\hline Lodoga 77-60 & 40 & 4 & 0 & 19 & 0 & 36 & 0 & 0 & & & 99 & 0.44 & 0.19 & 0.36 \\
\hline Lodoga 77-66 & 26 & 6 & 0 & 17 & 0 & 51 & 0 & 0 & & & 100 & 0.32 & 0.17 & 0.51 \\
\hline Lodoga 77-68 & 33 & 11 & 0 & 22 & 0 & 34 & 0 & 0 & & & 100 & 0.44 & 0.22 & 0.34 \\
\hline Lodoga 77-69 & 27 & 12 & 0 & 14 & 0 & 47 & 0 & 0 & & & 100 & 0.39 & 0.14 & 0.47 \\
\hline Lodoga $77-70$ & 26 & 10 & 0 & 15 & 0 & 48 & 0 & 0 & & & 99 & 0.36 & 0.15 & 0.48 \\
\hline PCC 07-PCC-10 & 71 & 9 & & 25 & 21 & 105 & 9 & 5 & 4 & 28 & 277 & 0.29 & 0.17 & 0.43 \\
\hline PCC 07-PCC-22 & 85 & 22 & & 32 & 30 & 94 & 11 & 17 & 9 & 33 & 333 & 0.32 & 0.19 & 0.37 \\
\hline PCC 07-PCC-23 & 78 & 19 & & 25 & 28 & 90 & 11 & 8 & 3 & 38 & 300 & 0.32 & 0.18 & 0.36 \\
\hline PCC data from Lindsley-Griffin et al., 1993 & & & & & & & & & & & & $\mathrm{P} / \mathrm{F}$ & $\mathrm{Qp} / \mathrm{Q}$ & $\mathrm{K} / \mathrm{F}$ \\
\hline PC-11 & & & & & & & & & & & & 0.60 & 0.60 & 0.40 \\
\hline PC-13 & & & & & & & & & & & & 0.73 & 0.42 & 0.26 \\
\hline PC-2 & & & & & & & & & & & & 0.77 & 0.61 & 0.23 \\
\hline PC-15 & & & & & & & & & & & & 0.85 & 0.40 & 0.15 \\
\hline
\end{tabular}

(0.814), with lower overlap between the Klamath River Conglomerate and Lodoga (0.685).

The degree of similarity between two samples includes both the number of ages (with associated uncertainties) that occur in both samples as well as their relative abundances in each sample, with one indicating a perfect match between samples and zero indicating no matching peaks. Again, all three units show a high degree of similarity, with the closest matches between the Pythian Cave conglomerate and Lodoga (0.886) and the Klamath River Conglomerate and Lodoga (0.882), and lower similarity between the Pythian Cave conglomerate and Klamath River Conglomerate (0.750).

Despite the visual similarities apparent in the probability density curves and the high degree of statistical overlap and similarity between these three units, Kolmogorov-Smirnoff (K-S) statistical analysis (Press et al., 1986) indicates that these three age distributions most likely do not come from the same populations. The K-S test determines a D-value that represents the maximum difference between two age distributions, and then calculates a Pvalue based on the significance level of an observed $\mathrm{D}$-value. The smaller the P-value, the more likely the observed difference between distributions is not random, and therefore the two samples are derived from different populations. The P-value for comparisons between all three units is much less than 0.05 , indicating that these age distributions are statistically different. The Dvalue calculated for each comparison shows the greatest observed difference between the Pythian Cave conglomerate and Klamath River Conglomerate $(D=0.387)$, less difference between the Klamath River Conglomerate and the Lodoga petrofacies $(D=0.275)$, and the smallest difference between the Pythian Cave conglomerate and the Lodoga petrofacies $(\mathrm{D}=0.185)$.

\section{Discussion}

\subsection{Pythian Cave conglomerate sediment source}

Cobble size, sandstone textural and compositional immaturity, and upland fluvial depositional environment all suggest a proximal source for the Pythian Cave conglomerate. Although the northern Klamath Mountains may have undergone significant post-Cretaceous rotation (as much as $67^{\circ}$ clockwise rotation of the Tertiary Tyee Formation, which onlaps northern Klamath terranes; e.g., Wells et al., 2000), the southeastern Klamath Mountains, with the overlying Pythian Cave conglomerate, appear to be relatively stable with respect to North America since the Late Jurassic (e.g., Mankinen and Irwin, 1990; Irwin and Wooden, 1999), with no more than $11.5 \pm 15.8^{\circ}$ clockwise rotation of Lower Cretaceous strata in the southern Klamath Mountains and no latitudinal translation (Mankinen and Irwin, 1982). Therefore, south to southwestdirected paleoflow indicators in the Pythian Cave conglomerate point to a source located to the north or northeast, relative to the current Pythian Cave conglomerate outcrop. Conglomerate clast composition and sandstone petrography describe a source dominated by a continental volcanic arc that provided abundant porphyritic and nonporphyritic volcanic rocks as well as granite.

The most proximal sediment source for the Pythian Cave conglomerate is the Klamath Mountains on which the Pythian Cave conglomerate was deposited. The ages of Early and Middle Jurassic plutonism in the Klamath Mountains match several of the smaller age peaks in the Pythian Cave conglomerate, and widespread Late Jurassic to Early Cretaceous plutonism matches the dominant age peak in the Pythian Cave conglomerate age distribution (Fig. 5). However, much of the Late Jurassic to Early Cretaceous magmatism 


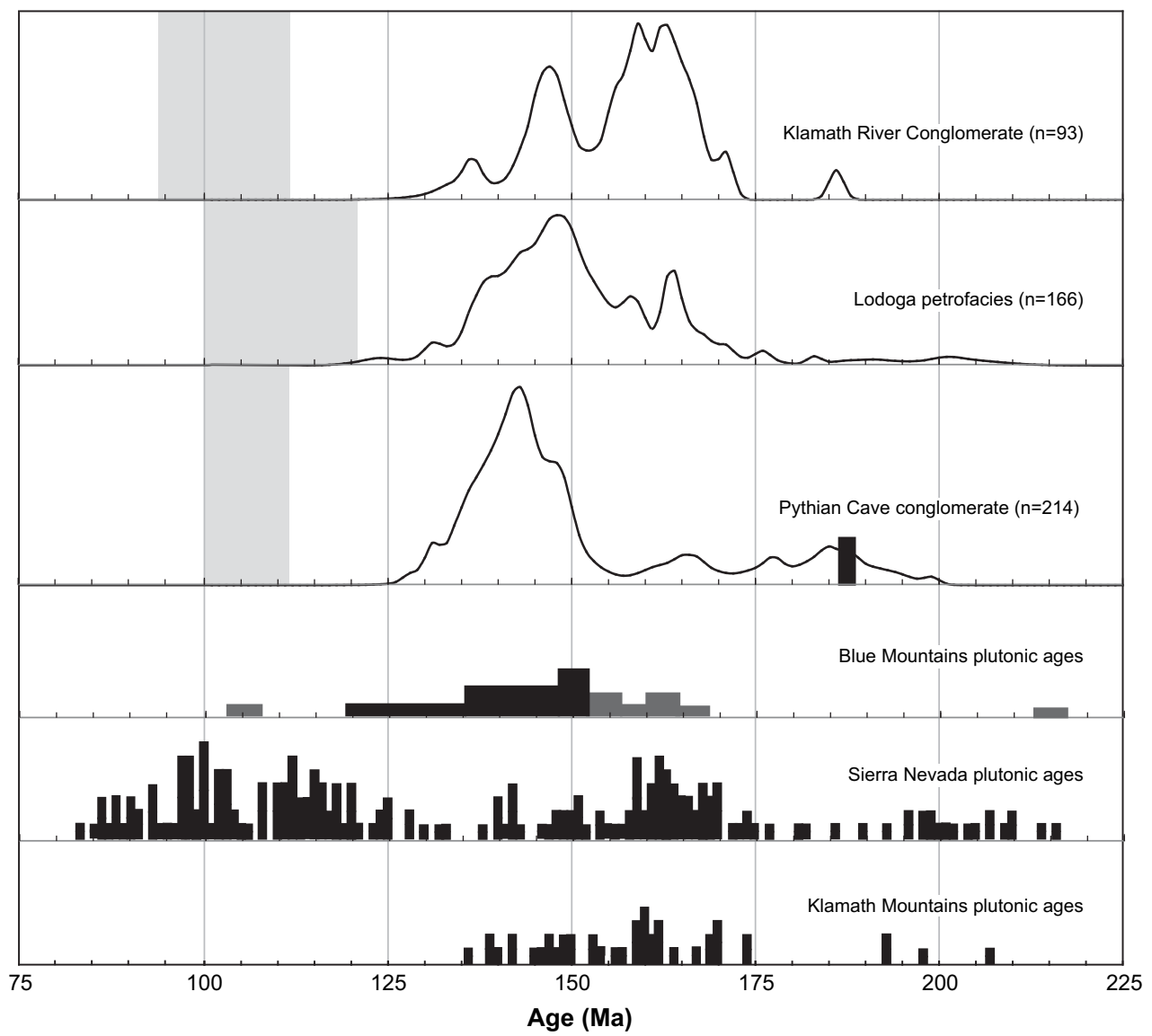

Fig. 5. Normalized probability density plots of detrital zircon age data from the Klamath River Conglomerate, Lodoga petrofacies, and Pythian Cave conglomerate. Light grey rectangles indicate depositional age of each unit and black rectangle on Pythian Cave conglomerate curve gives age of four dated granite cobbles. Histograms of dated plutonism (U$\mathrm{Pb}$ ages) in Klamath Mountains and Sierra Nevada from Irwin (2003) and references therein. Histogram of dated plutonism (K-Ar and Rb-Sr ages in dark grey and black) in Blue Mountains from Armstrong et al. (1977); range of U-Pb ages from Walker $(1989,1995)$ shown in black only.

in the Klamath Mountains occurred southwest to northwest of the Pythian Cave conglomerate (Fig. 1; Harper and Wright, 1984; Hacker et al., 1995; Irwin and Wooden, 1999), problematic if the Pythian Cave conglomerate source was proximal to the northeast. Early Cretaceous magmatism in the Klamath Mountains occurs largely south of the Pythian Cave conglomerate outcrop, again difficult to reconcile with paleocurrent directions. Moreover, the youngest ages in the Klamath Mountains are ca. 136 Ma (Shasta Bally batholith, Fig. 1; Lanphere and Jones, 1978) and the Pythian Cave conglomerate contains younger detrital zircon (Fig. 5). In addition, the Klamath Mountains would likely provide at least a few detrital zircon grains older than 200 Ma from both plutonic and metamorphic sources, but these ages are not found in the Pythian Cave conglomerate (Fig. 5). Furthermore, sediment shed from the series of accretionary belts and plutons that make up the Klamath Mountains (e.g., Hacker et al., 1995; Irwin and Wooden, 1999) would not likely be characterized by the abundant volcanic conglomerate clasts and sandstone volcanic lithic fragments that distinguish the Pythian Cave conglomerate. Thus, the Klamath Mountains may have been one source of sediment, but could not have been the only source.

The northern Sierran terranes and the Sierra Nevada batholith are currently exposed southeast of the Klamath Mountains and the Pythian Cave conglomerate. Several workers correlate terranes of the northern Sierran terranes and the Klamath Mountains, suggesting that these regions share a common petrotectonic history and were likely connected (e.g., Irwin, 2003; Ernst et al., 2008). The timing of Jurassic through Early Cretaceous magmatic events in the northern Sierran terranes corresponds well with that in the Klamath Mountains (Fig. 1) and also matches well with detrital zircon age peaks in the Pythian Cave conglomerate (Fig. 5). The western Sierra Nevada Mountains contain magmatic ages of 186-140 Ma (Stern et al., 1981; Bateman, 1983), with the intrusion of the main Cretaceous batholith occurring to the east from 125-82 Ma (Stern et al., 1981; Chen and Moore, 1982; Bateman, 1983). A Sierran source could provide the abundant continental arc volcanic rocks and lithic fragments present in the Pythian Cave conglomerate. However, despite mid-Albian deposition of the Pythian Cave conglomerate during the peak of emplacement of the main Cretaceous batholith, the batholith in the eastern Sierra Nevada clearly was not a source of Pythian Cave conglomerate sediment, as the youngest peak age in the Pythian Cave conglomerate is $131.8 \pm 2.5 \mathrm{Ma}$ and the youngest single grain is $129 \pm 1.5 \mathrm{Ma}$.

The Pythian Cave conglomerate paleocurrent direction is not consistent with a northern Sierran source, unless the northern Sierra Nevada volcanic arc extended further north in the Cretaceous than its present northern limits. This continental arc source may have been eroded or may now be buried under younger Tertiary volcanic cover, as suggested by previous workers (e.g., Wetzstein, 1986; Irwin, 2003). Alternatively, the Klamath Mountains and overlying Pythian Cave conglomerate may have been located south of their current position relative to the Sierra Nevada Mountains, thus placing the Cretaceous Pythian Cave conglomerate outcrop locality south-southwest of the northern Sierran terranes. 
However, Wyld et al.'s (2006) Cretaceous paleogeographic reconstruction of these Cordilleran terranes suggests that the Klamath Mountains moved approximately $400 \mathrm{~km}$ north to their modern position relative to the craton by $110 \mathrm{Ma}$, just prior to deposition of the Pythian Cave conglomerate. Moreover, if the Pythian Cave conglomerate was deposited further south relative to the Sierra Nevada Mountains, then younger, Early Cretaceous (Aptian-Albian) ages would be expected in the Pythian Cave conglomerate detrital zircon age distribution, as the north-trending main Cretaceous batholith would be much more proximal to a more southerly Pythian Cave conglomerate (Fig. 1).

The Blue Mountains province in northeastern Oregon (Fig. 6) presents a third possible source for the Pythian Cave conglomerate, as paleomagnetic studies indicate that the Blue Mountains underwent approximately $65^{\circ}$ clockwise rotation during Late Cretaceous and Cenozoic time (Wilson and Cox, 1980; Hillhouse et al., 1982; Mankinen and Irwin, 1990). Thus, the Blue Mountains restore to an Early Cretaceous location close to the Klamath Mountains and northern Sierran terranes (Fig. 7; Mankinen and Irwin, 1990). The Blue Mountains province includes the Izee, Wallowa, Baker, Grindstone, and Olds Ferry terranes that together represent a series of Permian-Triassic volcanic arc, intra-arc, and forearc complexes (Fig. 6; e.g., Vallier and Brooks, 1995). These terranes were intruded post-tectonically by mostly granitic plutons during the Late Jurassic to Early Cretaceous (Fig. 6; Armstrong et al., 1977). These Late Jurassic-Early Cretaceous plutons match ages in the Pythian Cave conglomerate well and would result in SSW-directed transport to the Pythian Cave conglomerate (Fig. 7a). However, the Blue Mountains province does not contain Early Jurassic ages present in the Pythian Cave conglomerate and may not have provided the abundant volcanic conglomerate clasts and lithic fragments characteristic of the Pythian Cave conglomerate.

When considered separately, neither the Klamath Mountains, northern Sierran terranes, nor Blue Mountains can fully account for the provenance characteristics of the Pythian Cave conglomerate, but provenance in the combined Blue Mountains-northern Sierran terranes presents the best match for the source ages, paleocurrent direction, and clast and sandstone composition in the Pythian Cave conglomerate (Fig. 7a). Given the paleomagnetic evidence for postEarly Cretaceous clockwise rotation of the Blue Mountains province (e.g., Mankinen and Irwin, 1990), combined with the presence of detrital zircon younger than $136 \mathrm{Ma}$ and the lack of Aptian-Albian detrital zircon in the Pythian Cave conglomerate, a sediment source in the combined Blue Mountains-northern Sierran terranes appears most likely, with possible input from the Klamath Mountains.

\subsection{Klamath River Conglomerate source}

Due to proximity, age, and unconformable deposition on the Klamath Mountains, the Pythian Cave conglomerate has been informally correlated with the Klamath River Conglomerate, the basal member of the Hornbrook Formation (Mack, 1960; Nilsen, 1984). However, the Pythian Cave conglomerate and Klamath River Conglomerate have nearly opposite paleocurrent directions (SSW for the Pythian Cave conglomerate and NNE for the Klamath River Conglomerate), very different conglomerate clast and sandstone compositions (Figs. 3 and 4), different depositional environments (upland fluvial for the Pythian Cave conglomerate and lowland fluvial

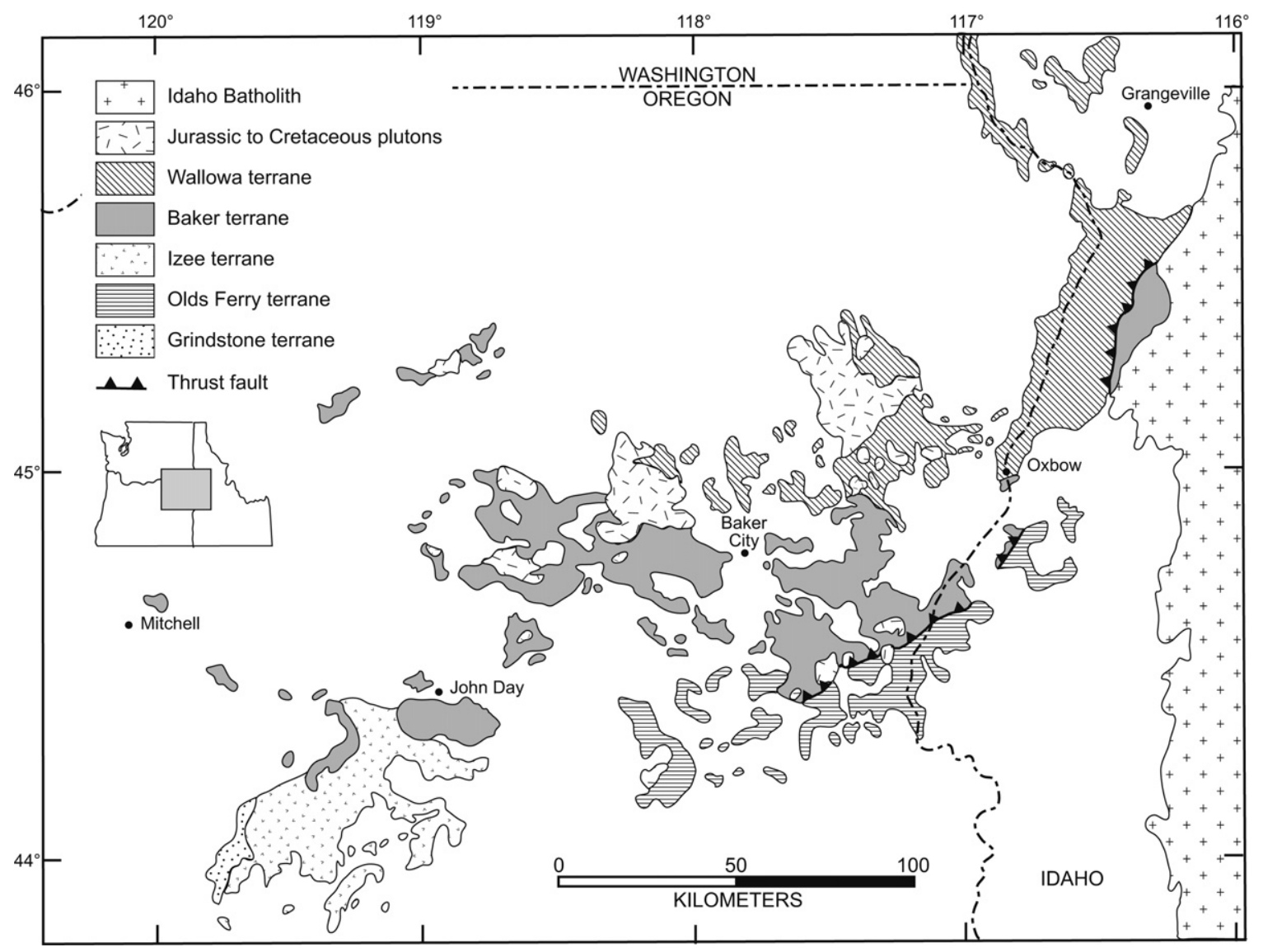

Fig. 6. Simplified terrane map of the Blue Mountains province and the Idaho batholith in northeastern Oregon and western Idaho (modified from Walker, 1995). 
a

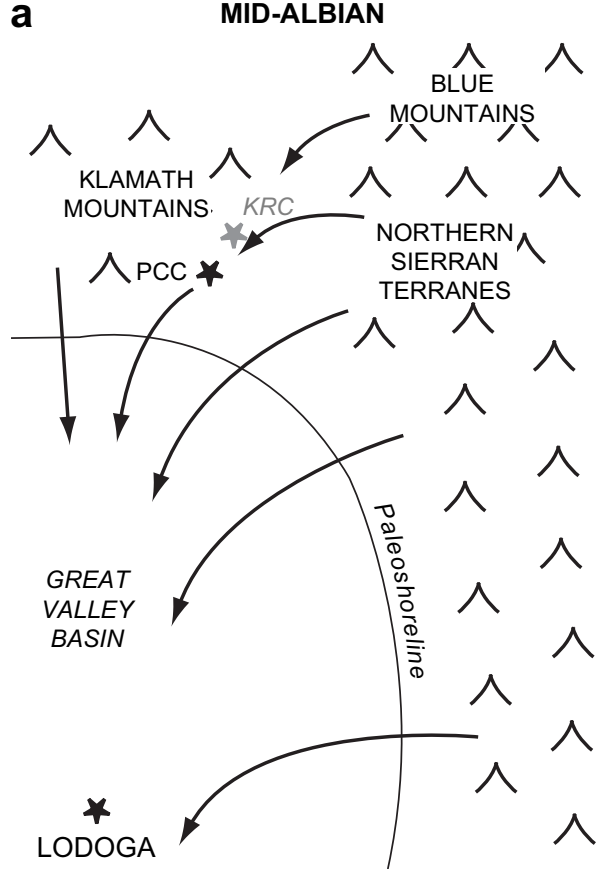

b

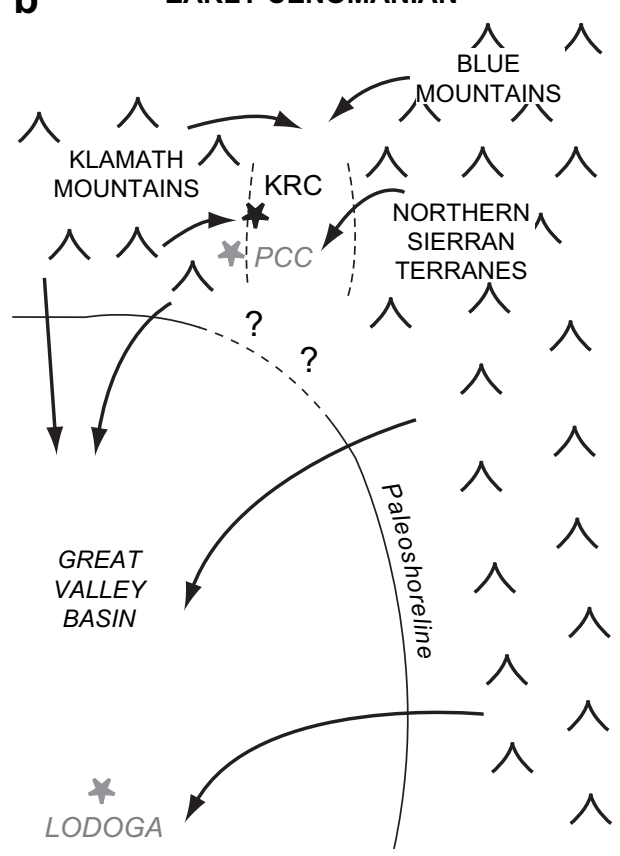

Fig. 7. Schematic tectonic model for the transition from Early to Late Cretaceous time. Arrows indicate paleodrainage directions, and grey stars and lettering indicate future (for KRC) or past (for PCC and Lodoga) location of deposition. a) Mid-Albian paleogeography showing a combined Blue Mountains-northern Sierran terranes proximal source for the Pythian Cave conglomerate, with southeast paleoflow continuing into the Great Valley basin and providing sediment to the Lodoga petrofacies. b) Early Cenomanian paleogeography showing westerly-derived Klamath Mountains provenance for the Klamath River Conglomerate and initial development of the Hornbrook basin. Sediment eroded from the Klamath Mountains and northern Sierran terranes continued to fill the Great Valley basin during Cenomanian time, but any connection between the Hornbrook and Great Valley basins is uncertain, as indicated by question marks.

to shallow marine for the Klamath River Conglomerate), and perhaps different depositional ages, with the mid-Albian Pythian Cave conglomerate slightly older than the mid-Cenomanian Klamath River Conglomerate (Jameossanaie and Lindsley-Griffin, 1993; LindsleyGriffin et al., 1993). The Klamath River Conglomerate's NNW paleocurrent direction, combined with abundant metamorphic clasts (especially quartzite; Fig. 3), smaller number of metavolcanic conglomerate clasts (Fig. 3), and sandstone provenance in transitional continental and recycled orogen (Fig. 4) led previous workers to interpret Klamath Mountains provenance for the Klamath River Conglomerate (e.g., Nilsen, 1984). A sediment source in the Klamath Mountains is consistent with new detrital zircon data, although the age data do not preclude either the northern Sierran terranes or the Blue Mountains province as additional sediment sources.

\subsection{Potential correlation of Pythian Cave conglomerate to the Great Valley Group}

Although detrital zircon age distributions from the Pythian Cave conglomerate and Klamath River Conglomerate are broadly similar (Fig. 5) with a high degree of overlap in ages, statistical comparisons between the Pythian Cave conglomerate and Klamath River Conglomerate resulted in lower similarity and the greatest observed difference (D-value) in the K-S statistical analysis. Notably, the Klamath River Conglomerate contains a Middle Jurassic peak that is nearly absent in the Pythian Cave conglomerate (Fig. 5). Detrital zircon age data, opposite paleocurrent directions, and different sandstone and conglomerate compositions all suggest that the Pythian Cave conglomerate likely represents a depositional system separate from and perhaps slightly older than the Klamath River Conglomerate and the rest of the Hornbrook Formation to the north.

Paleocurrent directions, depositional age, conglomerate clast composition (Fig. 3), and sandstone composition (Fig. 4) of the
Pythian Cave conglomerate and the Lodoga petrofacies of the Great Valley Group match very well, despite the distance between outcrop locations. The detrital zircon age distributions also show a closer match than the Pythian Cave conglomerate - Klamath River Conglomerate comparison, with the highest degree of statistical similarity and the smallest observed D-value in the K-S statistical analysis. Both the Pythian Cave conglomerate and the Klamath River Conglomerate derived sediment from the combined KlamathSierran-Blue Mountains arc, with the Lodoga petrofacies receiving potentially more Sierran-derived sediment through transverse transport in the Great Valley basin (Fig. 7a). Thus, the Pythian Cave conglomerate may represent an erosional remnant of the nearsource equivalent of the more distal Lodoga petrofacies deposited further south in the Great Valley basin.

\subsection{Implications for regional tectonics}

The provenance of the Pythian Cave conglomerate requires the presence of a volcanic arc source east of the Klamath Mountains during the Early Cretaceous, which may have been an extension of the Sierra Nevadan arc combined with the restored Blue Mountains province (Fig. 7). Clear differences between the Pythian Cave conglomerate and Klamath River Conglomerate require that this eastern arc source did not contribute significant sediment to the Klamath River Conglomerate. As subsidence in the newly-forming Hornbrook basin transgressed south, perhaps combined with uplift in the Klamath Mountains and erosion of arc-derived sediment, the Albian fluvial system from the arc to the east was cut off, and sediment in the Klamath River Conglomerate of the Hornbrook Formation derived largely from more deeply-eroded metamorphic basement that lay below the fluvial volcaniclastic cover (Fig. 7b; e.g., Lindsley-Griffin et al., 1993). In this model, the mid-Albian Pythian Cave conglomerate represents an erosional remnant of 
more widespread fluvial volcaniclastic deposits derived from a Blue Mountains-northern Sierran continental volcanic arc to the north and east, and the slightly younger basal Hornbrook Formation resulted from erosion of the underlying metamorphic basement (e.g., Lindsley-Griffin et al., 1993). However, if the Klamath River Conglomerate is older than mid-Cenomanian in some areas, then the Pythian Cave conglomerate and Klamath River Conglomerate were occasionally syndepositional, and a local drainage divide between the two could account for their very different provenance.

The similarity of the Pythian Cave conglomerate with coeval sedimentation in the Great Valley basin to the south is consistent with a paleogeographic model for the Early Cretaceous Great Valley Group that reconstructs a continuous Klamath-Sierran magmatic arc with sediment transport south and east into the Great Valley forearc basin (Short and Ingersoll, 1990), with the addition of the restored Blue Mountains province as an additional sediment source (Fig. 7a). Thus, the Early Cretaceous Great Valley forearc basin remained separate from the transgressing Hornbrook basin to the north. With further basin subsidence, possible uplift in the Klamath Mountains, and greater sedimentation in both the Great Valley and Hornbrook basins, this separation may have disappeared during the Late Cretaceous, perhaps resulting in one large forearc system, as suggested by previous workers (Fig. 7b; e.g., Miller et al., 1992; Nilsen, 1984, 1993).

Wright and Wyld (2007) proposed that the Great Valley Group was deposited in a translational forearc system and postulated the existence of a Great Valley strike-slip fault that accommodated several hundreds of kilometers of dextral offset in the Late Jurassic-Early Cretaceous. Their model suggests that the lower Great Valley Group prior to strike-slip offset was offshore of the continental arc in the southwest Cordillera, thus requiring a very different source from the more northerly Klamath-Sierran source terranes of the upper Great Valley Group (Wright and Wyld, 2007). Potential correlation of the Pythian Cave conglomerate and Lodoga petrofacies of the Great Valley Group requires that any proposed northward translation of the Great Valley Group was complete by the mid-Albian deposition of the Pythian Cave conglomerate, if not by Aptian-Albian deposition of the Lodoga petrofacies.

Notably, neither the Pythian Cave conglomerate nor the Lodoga petrofacies contain zircon ages derived from the main Cretaceous batholith of the Sierra Nevada Mountains (younger than $125 \mathrm{Ma}$ ), suggesting that a drainage divide existed between the developing batholith and sediments in the forearc basin to the west, so that sediment derived from main Cretaceous magmatism was shed to the north, east, and/or south, but not west. Alternatively, the volcanic rocks associated with the main Cretaceous magmatic event were eroded west into the forearc basin, but contained little to no zircon. Abundant 125-85 Ma zircon appears in the Upper Cretaceous Great Valley Group (DeGraaff-Surpless et al., 2002) and in the Upper Cretaceous Hornbrook Formation (Beverly et al., 2008), indicating that the main Cretaceous batholith was a significant sediment source to basins to the west and north during the Late Cretaceous.

\section{Conclusions}

Provenance characteristics of the Pythian Cave conglomerate provide valuable information about the paleogeography of the northern Cordilleran terranes during Cretaceous time. The source of the Pythian Cave conglomerate was likely the combined Blue Mountains-northern Sierran terranes, with paleoflow directed to the west-southwest. Conglomerate and sandstone derived from this complex eastern arc source formed the Pythian Cave conglomerate in an upland fluvial environment, with sediment deposited unconformably on the Yreka terrane of the Eastern Klamath terranes. Finer sediment likely continued south into the Great
Valley basin, contributing sediment to the Lodoga petrofacies of the Great Valley Group. By Cenomanian time, subsidence of the Hornbrook basin east of the Klamath Mountains shifted paleoflow directions in the region to the west-northwest of the Pythian Cave conglomerate to form the Klamath River Conglomerate in a lowland fluvial, alluvial, or shallow marine environment. Sediment derived from the Klamath Mountains and northern Sierran terranes continued to be deposited in the Great Valley basin to the south, but it remains unclear if the Hornbrook and Great Valley basins were connected. These provenance results support previous interpretations that the Pythian Cave conglomerate is not related to the Hornbrook Formation and does not have a Klamath Mountains provenance (Lindsley-Griffin et al., 1993). Moreover, these results suggest the existence of a combined Cretaceous Blue MountainsSierran arc east of the Klamath Mountains, and link the Great Valley Group to the Klamath Mountains by Albian time.

\section{Acknowledgements}

The authors wish to thank Victor Valencia and George Gehrels of the LaserChron Center at the University of Arizona for their assistance in preparing and analyzing detrital zircon from the Pythian Cave conglomerate and the Klamath River Conglomerate, and in processing these age data. The authors are grateful for the help of Joe Wooden and Brad Ito for their assistance in analyzing detrital zircon from the Lodoga petrofacies on the Sensitive High-Resolution Ion MicroProbe - Reverse Geometry (SHRIMP-RG), jointly directed by the U.S. Geological Survey and Stanford University. The authors were greatly assisted by Emily Beverly in the field and in preparation of samples. Comments and suggestions from two anonymous reviewers improved this manuscript. This research was funded by ACS-PRF Grant \#45737-B8 to PI Surpless and Trinity University Special Projects Grants.

\section{Appendix. Supplementary data}

Supplementary data associated with this article can be found in online version at doi:10.1016/j.cretres.2009.05.005

\section{References}

Armstrong, R.L., Taubeneck, W.H., Hales, P.O., 1977. Rb-Sr and K-Ar geochronometry of Mesozoic granitic rocks and their $\mathrm{Sr}$ isotopic composition, Oregon, Washington, and Idaho. Geological Society of America Bulletin 88, 391-411.

Augsburger, G.A., Surpless, K.D., Beverly, E.J., 2008. Provenance analysis of the Cretaceous Pythian Cave conglomerate, northern California. Geological Society of America - Abstracts with Programs 40 (no. 1), 55

Barats, G.M., Nilsen, T.H., Golia, R.T., 1984. Conglomerate clast composition of the Upper Cretaceous Hornbrook Formation, Oregon and California. In: Nilsen, T.H. (Ed.), Geology of the Upper Cretaceous Hornbrook Formation, Oregon and California, 42. Pacific Section Society of Economic Paleontologists and Mineralogists, pp. 111-122.

Bateman, P.C., 1983. A summary of the critical relations in the central part of the Sierra Nevada Batholith. Geological Society of America Memoir 159, 241-252.

Bertucci, P.F., 1983. Petrology and provenance of the Stony Creek Formation, northwestern Sacramento Valley, California. In: Bertucci, P.F., Ingersoll, R.V (Eds.), Guidebook to the Stony Creek Formation, Great Valley Group, Sacramento Valley, California. Pacific Section, Society of Economic Paleontologists and Mineralogists, pp. 1-16.

Beverly, E.J., Surpless, K.D., Augsburger, G.A., 2008. Provenance analysis of the Cretaceous Hornbrook Formation of northern California and southern Oregon: evidence for a non-Klamath Cretaceous arc source. Geological Society of America Abstracts with Programs 40 (no. 1), 55.

Bralower, T.J., Ludwig, K.R., Obradovich, J.D., Jones, D.L., 1990. Berriasian (Early Cretaceous) radiometric ages from the Grindstone Creek Section, Sacramento Valley, California. Earth and Planetary Science Letters 98, 62-73.

Chen, J.H., Moore, J.G., 1982. Uranium-lead isotopic ages from the Sierra Nevada Batholith, California. Journal of Geophysical Research 87, 4761-4784. 
Cowan, D.S., Brandon, M.T., Garver, J.I., 1997. Geological tests of hypotheses for large coastwise displacements; a critique illustrated by the Baja British Columbia controversy. American Journal of Science 297, 117-173.

DeGraaff-Surpless, K., Graham, S.A., Wooden, J.L., McWilliams, M.O., 2002. Detrital zircon provenance analysis of the Great Valley Group, California: evolution of an arc-forearc system. Geological Society of America Bulletin $114,1564-1580$

DeGraaff-Surpless, K., Mahoney, J.B., Wooden, J.L., McWilliams, M.O., 2003. Lithofacies control in detrital zircon provenance studies: insights from the Cretaceous Methow Basin. Geological Society of America Bulletin 115, 899-915.

Dickinson, W.R., 1970. Relations of andesites, granites, and derivative sandstones to arc-trench tectonics. Reviews of Geophysics and Space Physics 8, 813-860.

Dickinson, W.R., 2004. Evolution of the North American Cordillera. Annual Reviews of Earth and Planetary Sciences 32, 13-45.

Dickinson, W.R., Rich, E.I., 1972. Petrologic intervals and petrofacies in the Great Valley Sequence, Sacramento Valley, California. Geological Society of America Bulletin 83, 3007-3024.

Dickinson, W.R., Beard, S.L., Brakenridge, G.R., Erjavec, J.L., Ferguson, R.C., Inman, K.F., Knepp, R.A., Lindberg, F.A., Ryberg, P.T., 1983. Provenance of North American Phanerozoic sandstones in relation to tectonic setting. Geological Society of America Bulletin 94, 222-235.

Ernst, W.G., Snow, C.A., Scherer, H.H., 2008. Contrasting early and late Mesozoic petrotectonic evolution of northern California. Geological Society of America Bulletin 120, 179-194.

Gehrels, G.E., Valencia, V., Pullen, A., 2006. Detrital zircon geochronology by laserablation multicollector ICPMS at the Arizona LaserChron Center. In: Olszewski, T. (Ed.), Geochronology: Emerging Opportunities, Paleontological Society Short Course. Paleontological Society Papers 12, 67-76. Philadelphia.

Golia, R.T., Nilsen, T.H., 1984. Sandstone petrography of the Upper Cretaceous Hornbrook Formation, Oregon and California. In: Nilsen, T.H. (Ed.), Geology of the Upper Cretaceous Hornbrook Formation, Oregon and California. Pacific Section Society of Economic Paleontologists and Mineralogists 42, 99-109.

Graham, S.A., Ingersoll, R.V., 1981. Field trip road log; Great Valley Group submarine fan facies and Sacramento Valley forearc gas province; (Part I), Sacramento to Cache Creek and return. In: Graham, S.A. (Ed.), Field Guide to the Mesozoic-Cenozoic Convergent Margin of Northern California. Pacific Section, American Association of Petroleum Geologists, Santa Fe Springs, pp. $71-78$.

Hacker, B.R., Donato, M.M., Barnes, C.G., McWilliams, M.O., Ernst, W.G., 1995. Timescales of orogeny: jurassic construction of the Klamath mountains. Tectonics 14, 677-703.

Haggart, J.W., Enkin, R.J., Monger, J.W.H., 2006. Strengths and limitations of paleogeographic methods in assessing large-scale displacements within the North American Cordillera. In: Haggart, J.W., Enkin, R.J., Monger, J.W.H. (Eds.), Paleogeography of the North American Cordillera: Evidence for and against Large-scale Displacements. Geological Association of Canada Special Paper 46, $1-11$.

Harper, G.D., Wright, J.E., 1984. Middle to Late Jurassic tectonic evolution of the Klamath Mountains, California-Oregon. Tectonics 3, 759-772.

Hillhouse, J.W., Gromme, C.S., Vallier, T.L., 1982. Paleomagnetism and Mesozoic tectonics of the Seven Devils volcanic arc in northeastern Oregon. Journal of Geophysical Research 87, 3777-3794.

Hotz, P.E., 1977. Geology of the Yreka quadrangle, Siskiyou County, California. United States Geological Survey Bulletin 1436, 72.

Housen, B.A., Dorsey, R.J., 2005. Paleomagnetism and tectonic significance of Albian and Cenomanian turbidites, Ochoco Basin, Mitchell Inlier, central Oregon. Journal of Geophysical Research 110, 22.

Imlay, R.W., Jones, D.L., 1970. Ammonites from the Buchia zones in northwestern California and southwestern Oregon. United States Geological Survey Professional Paper 647-B, 55.

Ingersoll, R.V., 1979. Evolution of the Late Cretaceous forearc basin, northern and central California. Geological Society of America Bulletin 90, 1813-1826.

Ingersoll, R.V., 1981. Petrofacies, lithofacies, submarine-fan facies of the Great Valley Group (Sequence). In: Graham, S.A. (Ed.), Field Guide to the Mesozoic-Cenozoic Convergent Margin of Northern California. Pacific Section, American Association of Petroleum Geologists, Santa Fe Springs, pp. 59-69.

Ingersoll, R.V., 1983. Petrofacies and provenance of late Mesozoic forearc basin, Northern and Central California. American Association of Petroleum Geologists Bulletin 67, 1125-1142.

Irwin, W.P., 1981. Tectonic accretion of the Klamath Mountains. In: Ernst, W.G. (Ed.), The Geotectonic Evolution of California (Rubey Volume I). Prentice Hall, Englewood Cliffs, pp. 29-49.

Irwin, W.P., Wooden, J.L., 1999. Plutons and accretionary episodes of the Klamath Mountains, California and Oregon. United States Geological Survey Open-File Report 99-0374.

Irwin, W.P., 2003. Correlation of the Klamath Mountains and Sierra Nevada. United States Geological Survey Open-File Report 02-490, Scale 1:1,000,000, 2 sheets.

Jameossanaie, A., Lindsley-Griffin, N., 1993. Palynology and plate tectonics: a case study on Cretaceous terrestrial sediments in the eastern Klamath mountains of northern California, USA. Palynology 17, 11-45.

Jones, D.L., Bailey, E.H., Imlay, R.W., 1969. Structural and stratigraphic significance of the Buchia zones in the Colyear Springs-Paskenta area, California. United States Geological Survey Special Paper 647-A, 21.
Lanphere, M.A., Jones, D.L., 1978. Cretaceous time scale from North America. In: Contributions to the Geologic Time Scale, 6. American Association of Petroleum Geologists Studies in Geology, pp. 259-268.

Lindsley-Griffin, N., Griffin, J.R., Wetzstein, E.E., Jameossanaie, A., 1993. Post-accretion history of a Cretaceous overlap sequence in northern California. In: Dunne, G., McDougall, K. (Eds.), Mesozoic Paleogeography of the Western United States II, Book 71. Pacific Section SEPM, pp. 99-112.

Lindsley-Griffin, N., Griffin, J.R., Farmer, J.D., 2008. Paleogeographic significance of Ediacaran cyclomedusoids within the Antelope Mountain Quartzite, Yreka terrane, eastern Klamath Mountains, California. In: Blodgett, R.W., Stanley Jr., G.D. (Eds.), The Terrane Puzzle: New Perspectives on Paleontology and Stratigraphy from the North American Cordillera. Geological Society of America Special Paper 442, 1-37.

Mack, S., 1960. Geology and ground-water resources of Shasta Valley, Siskiyou County, California. United States Geological Survey Water Supply Paper 1484, 115.

Mankinen, E.A., Irwin, W.P., 1982. Paleomagnetic study of some Cretaceous and Tertiary sedimentary rocks of the Klamath Mountains province, California. Geology 10, 82-87.

Mankinen, E.A., Irwin, W.P., 1990. Review of paleomagnetic data from the Klamath Mountains, Blue Mountains and Sierra Nevada: implications for paleogeographic reconstructions. In: Harwood, D.S., Miller, M.M. (Eds.), Paleozoic and Early Mesozoic Paleogeographic Relations; Sierra Nevada, Klamath Mountains, and Related Terranes. Geological Society of America Special Paper 255, 397-407. Boulder, Colorado.

Miller, M.M., 1987. Dispersed remnants of a northeast Pacific fringing arc; Upper Paleozoic terranes of Permian McCloud faunal affinity, western U.S. Tectonics 6, 807-830.

Miller, D.M., Nilsen, T.H., Bilodeau, W.L., 1992. Late Cretaceous to early Eocene geologic evolution of the U.S. Cordillera. In: Burchfiel, B.C., Lipman, P.W., Zoback, M.L. (Eds.), The Cordilleran Orogen: Conterminous U.S. Boulder, Colorado. Geological Society of America, The Geology of North America G-3, pp. 205-260.

Monger, J.W.H., 1977. Upper Paleozoic rocks of the western Canadian Cordillera and their bearing on Cordilleran evolution. Canadian Journal of Earth Sciences 14, $1832-1859$.

Moxon, I.W., 1988. Sequence stratigraphy of the Great Valley basin in the context of convergent margin tectonics. In: Graham, S.A., Olson, H.C. (Eds.), Studies of the Geology of the San Joaquin Basin, 60. Los Angeles, Field Trip Guidebook, Pacific Section, Society of Economic Paleontologists and Mineralogists, pp. 3-28.

Moxon, I.W., 1990. Stratigraphic and structural architecture of the San JoaquinSacramento Basin (Ph.D. thesis). Stanford University, p. 371

Nilsen, T.H., 1984. Stratigraphy, sedimentology, and tectonic framework of the Upper Cretaceous Hornbrook Formation, Oregon and California. In: Nilsen, T.H. (Ed.), Geology of the Upper Cretaceous Hornbrook Formation, Oregon and California, 42. Pacific Section Society of Economic Paleontologists and Mineralogists, pp. $51-88$

Nilsen, T.H., 1993. Stratigraphy of the Cretaceous Hornbrook Formation, southern Oregon and northern California. United States Geological Survey Professional Paper 1521, 89

Ojakangas, R.W., 1968. Cretaceous sedimentation, Sacramento Valley, California. Geological Society of America Bulletin 79, 973-1008.

Poldervaart, A., 1956. Zircons in Rocks II., Igneous rocks. American Journal of Science 254, 521-554.

Press, W.H., Flannery, B.P., Teukolsky, S.A., Vetterling, W.T., 1986. Numerical Recipes, The Art of Scientific Computing. Cambridge University Press, Cambridge, pp. 186.

Short, P.F., Ingersoll, R.V., 1990. Petrofacies and provenance of the Great Valley Group, southern Klamath Mountains and northern Sacramento Valley. In: Ingersoll, R.V., Nilsen, T.H. (Eds.), Sacramento Valley Symposium and Guidebook, vol. 65. Pacific Section Society of Economic Paleontologists and Mineralogists, pp. 39-52.

Stern, T.W., Bateman, P.C., Morgan, B.A., Newell, M.F., Peck, D.L., 1981. Isotopic U-Pb ages of zircon from the granitoids of the central Sierra Nevada, California. Reston. United States Geological Survey Professional Paper 1185, 19.

Vallier, T.L., Brooks, H.C. (Eds.), 1995. Geology of the Blue Mountains Region of Oregon, Idaho, and Washington: Petrology and Tectonic Evolution of PreTertiary Rocks of the Blue Mountains Region. United States Geological Survey Professional Paper 1438, 540.

Walker, N.W., 1989. Early Cretaceous initiation of post-tectonic plutonism and the age of the Connor Creek Fault, northeastern Oregon. Geological Society of America - Abstracts with Programs 21 (no. 5), 155.

Walker, N.W., 1995. Tectonic implications of U-Pb zircon ages of the Canyon Mountain Complex, Sparta Complex, and related metaplutonic rocks of the Baker Terrane, northeastern Oregon. In: Vallier, T.L., Brooks, H.C. (Eds.), Geology of the Blue Mountains Region of Oregon, Idaho, and Washington: Petrology and Tectonic Evolution of Pre-Tertiary Rocks of the Blue Mountains Region. United States Geological Survey Professional Paper 1438, 247-269.

Ward, P.D., Hurtado, J.M., Kirschvink, J.L., Verosub, K.L., 1997. Measurements of the Cretaceous paleolatitude of Vancouver Island: consistent with the Baja-British Columbia hypothesis. Science 277, 1642-1645.

Watson, E.B., 1979. Zircon saturation in felsic liquids: experimental data and applications to trace element geochemistry. Contributions to Mineralogy and Petrology 70, 407-419.

Wells, R.E., Jayko, A.S., Niem, A.R., Black, G., Wiley, T., Baldwin, E., Molenaar, K.M., Wheeler, K.L., DuRoss, C.B., Givler, R.W., 2000. Geologic map and database of the 
Roseburg $30 \times 60^{\prime}$ quadrangle, Douglas and Coos Counties, Oregon. United States Geological Survey Open File Report 00-376.

Wetzstein, E.E., 1986. Sedimentology and tectonic significance of a Cretaceous conglomerate in the eastern Klamath Mountains, California (Master's Thesis). Lincoln, Nebraska, p.53.

Williams, T.A., 1997. Basin-fill architecture and forearc tectonics: Cretaceous Grea Valley Group, Sacramento Basin, northern California (Ph.D. thesis). Stanford University, p. 412.

Wilson, D., Cox, A., 1980. Paleomagnetic evidence for tectonic rotation of Jurassic plutons in Blue Mountains, eastern Oregon. Journal of Geophysical Research 85 , 3681-3689.
Wright, J.E., Wyld, S.J., 2007. Alternative tectonic model for Late Jurassic through Early Cretaceous evolution of the Great Valley Group, California. In: Cloos, M. Carlson, W.D., Gilbert, M.C., Liou, J.G., Sorenson, S.S. (Eds.), Convergent Margin Terranes and Associated Regions; a Tribute to W.G. Ernst. Geological Society of America Special Paper 419, 81-95. Boulder.

Wyld, S.J., Umhoefer, P.J., Wright, J.E., 2006. Reconstructing northern Cordilleran terranes along known Cretaceous and Cenozoic strike-slip faults: implications for the Baja British Columbia hypothesis and other models. In: Haggart, J.W. Enkin, R.J., Monger, J.W.H. (Eds.), Paleogeography of the North American Cordillera: Evidence for and Against Large-scale Displacements. Geological Association of Canada Special Paper 46, 277-298. 